\title{
Wiley
}

\section{A Trip to Harar and Imé}

Author(s): H. G. C. Swayne

Source: The Geographical Journal, Vol. 2, No. 3 (Sep., 1893), pp. 250-252

Published by: geographicalj

Stable URL: http://www.jstor.org/stable/1773666

Accessed: 15-04-2016 00:51 UTC

Your use of the JSTOR archive indicates your acceptance of the Terms \& Conditions of Use, available at

http://about.jstor.org/terms

JSTOR is a not-for-profit service that helps scholars, researchers, and students discover, use, and build upon a wide range of content in a trusted digital archive. We use information technology and tools to increase productivity and facilitate new forms of scholarship. For more information about JSTOR, please contact support@jstor.org.

Wiley, The Royal Geographical Society (with the Institute of British Geographers) are collaborating with JSTOR to digitize, preserve and extend access to The Geographical Journal 
importance of the latter town as an emporium of commerce, before it had been ruined by the incessant attacks made on the Portuguese there, both by the Dutch and by neighbouring native princes; thus confirming the acounts of Varthema and other travellers of that period. With regard to the Dutch attacks on Malacca it may be noticed that none seems to be mentioned of so early a date as that which Gabriel Towerson describes in a letter published in the Hakluyt Society's edition of Sir H. Middleton's voyage.

The details of the rapid rise of the Portuguese power in the far East, and of its no less rapid decline, are by no means widely known; and this report will undoubtedly be of service to those inclined to carry on researches in this interesting field of enquiry.

\section{A TRIP TO HARAR AND IMÉ.}

\section{By Captain H. G. C. SWAYNE, R.E.*}

Captain Swayne, who has been on a sporting expedition in Somaliland, writes from Aden:-I started from Bulhar on February 16th, and went to Jig-Jiga, where I found an Abyssinian guard of twenty men posted in their stockaded fort over the wells. I had twenty-five Somalis, all told. Next day, an Abyssinian chief called Banagusé Fi Taurari marched into the stockade from Gojai, about 20 miles to the west, accompanied by about three hundred and fifty horse and foot, to resist the supposed invader, the Somalis having exaggerated my trip into a British invasion. Nearly all the Abyssinians carried good Remingtons. Banagusé seemed inclined at first to arrest me, but on hearing I had come up in order to visit Ras Makuwan, the Harar governor, he was afraid to do so. I sent a letter to Makuwan, and after I had waited at Jig-Jiga a few days, one Gakatagli came with a very polite note from the Ras, asking me to come to Harar.

On nearing Harar I found I had to pass through two lines of soldiers, to the number of about a thousand, brought out to escort me, by order of the Ras, who is very hospitably inclined to the English. Each company presented arms as I passed along the path between the lines. I remained at Harar five days, a guest at the house of Alaka Gobau Desta; and before leaving I gave the Ras an Indian tiger-skin and an album of Indian photographs; receiving in return his photograph, a silver-mounted shield, spears, saddlery, and a good mule, also a passport ordering any soldiers whom I might encounter in Ogaden to treat me courteously. I also received much kindness from Count Salimbeni and the Europeans at Harar.

* Captain Swayne's route will be indicated upon a sketch-map illustrating Signor Bricchetti-Robecchi's 'Travels in the Somali Country,' in the October number. 
Returning to Jig-Jiga, I made my way to Kuredelli, in the Jerer Valley, and began shooting from that place, getting a lioness and rhinoceros one night over the water. I went on down the Jerer Valley, getting two more rhinoceroses at Tulli, and a panther. Leaving Milmil three days to the east, I turned at right angles, and marched to Dagaha-madoba, getting another panther. Thence I went to Segag, one of Captain Baudi's camps, he having gone to Imé some three years ago. Near Segag, in a valley called Daghatto, I shot a bull elephant. I went on through the Malingur tribe, and after some difficulty opened up communication with the Rer Amaden tribe. Jama Deria, a minstrel, or bard, known all over Somaliland, was very polite, and advised me, if I wished to go to Imé, to leave my caravan with him at Dambas Werer, while he would lend me five ponies and the services of his son and two headmen, and we should all ride to Imé together.

With Jama Deria, his son, and two others, and three of my own men, on two Arab fast camels, one mule, and five ponies, I went to Imé and back within six days (150 miles), during nearly four of which I remained at Imé the guest of the Adone chief, Gabba Oboho, and hunted the "balanka," or waterbuck. On approaching Imé, I found the negro (Adone) inhabitants collected on the hills across the river, having deserted their huts, fearing our small cavalcade was the reconnoitring advance-guard of an Abyssinian force. The Imé people were all calling themselves British "subjects." In fact everybody except the Malingur Agaden did so. The Malingur living in the Tug Fafan Valley are in the great eastward path of invasion by the Abyssinians, hence they have had to give in to them. But the Rer Amaden have inflicted great loss on the Abyssinians from time to time. I saw the remains of the bivouac of an enormous Abyssinian army which had been defeated some two or three years before. The forest fringing the Webbe, for 100 yards on either side, is very fine at Imé, consisting chiefly of tall casuarinas and evergreens. The river is about 100 yards wide or so. Waterbuck were very common. There had been war between the Amaden and the Imé, Adone, and Somalis of Karaulé, so the country between Dambas Werer and Imé was quite empty. The Arussi Gallas, who live to the south-west, from Segag to Imé, are the great bugbear, as they raid the Somalis occasionally all along that line of country. Old Gabba promised to take me to the Gure Gallas, to the south-east of Imé, where there are said to be buffaloes and giraffes. They have a good road to Logh above Bardera, on the Jub or Webbe Ganana. Gabba said when I was there (in May), "Come in two months' time, when you can ford the Webbe with your camels."

Finding my leave nearly at an end, I returned as fast as possible by the way I had come, halting only once for a day at Jama Deria's own karias. At Durhi I was so unfortunate as to lose one of my best men, carried off by a man-eating lion while riding alone in the jungle. I 
shot a lion near Segag, and a large number of the zebras which have, I believe, lately been classified as "Grevy's zebras." Their meat forms a favourite article of food among the Rer Amaden. My followers were. unfortunate on this trip; one man had his leg broken by the fall of a camel, another quarrelled with an Abyssinian and got a spear through the hand, and a third was badly scratched by a panther which we were following at night. I lost eight camels out of the thirty, owing to the rapid marching and the bad state in which $I$ found them before starting. The Somalis also consider that two died solely from the bite of the "balaad" fly of Ogaden, specimens of which I secured. The "dug" is another bad fly, but not so deadly as the balaad.

I returned by Milmil and the Habr Gerhaji's country. At Aden I found I had received six months' extension of leave, and I return tomorrow to Berbera and start for Imé afresh, with the object of doing a good private survey if possible in the country of the Gure Gallas beyond Imé; though of course my main reason for these journeys is to open up new shooting grounds. My followers place all the difficulties they can in my way, because they are afraid of the Galla country, but I am taking two interpreters who are Gallas themselves. I shall take forty rifles to Imé, and engage also Galla and Adone followers. up there.

\section{THE PHYSICAL GEOGRAPHY OF ANTARCTICA.}

IF the most certain method of stimulating research in a special subject is to set forth. the total inadequacy of present knowledge, to answer questions raised in the setting of it, Dr. Karl Fricker's exhaustive if somewhat diffuse paper on "Die Entstehung und Verbreitung des Antarktischen Treibeises" should be to scientific explorers as grapes from an Antarctic Eschol. The contributions of Payer in Franz Josef Land and of Nansen in Greenland to our knowledge of the structure and motion of Arctic glaciers, as distinguished from Alpine or strictly valley glaciers, have thrown new light on the work of the few navigators who have as yet crossed the Antarctic circle, and a review of the subject from the more recent standpoint is excellent preparation for further personal inquiry.

The occurrence of drift-ice in the southern seas, although observed at an early date, is not a frequent entry in ships' log-books until near the end of the seventeenth century; the rediscovery of Le Maire Strait in 1616 having gradually led bolder navigators to forsake the, up to that time, invariable passage of the Straits of Magellan. Land had been discovered on the first attempt to reach higher southern latitudes by Amerigo Vespucci, who in 1502 found uninhabited land somewhere near the parallel of $50^{\circ} \mathrm{S}$. Considerable doubt remains as to the identity of the land mentioned by Vespucci, uncertainty as to certain passages in his journal, and inherent errors in the determination of positions, leaving the choice of the east coast of Patagonia, the Falkland Islands, and South Georgia. Dr. Fricker inclines to select the last. Drake's Antarctic explorations seem distinctly apocryphal, and the next visitor to those parts was the Dutch pirate, Dirk Gerritz, who in 1599 was driven south from the Straits of Magellan by a s-vere gale, probably as far as $64^{\circ} \mathrm{S}$. 